
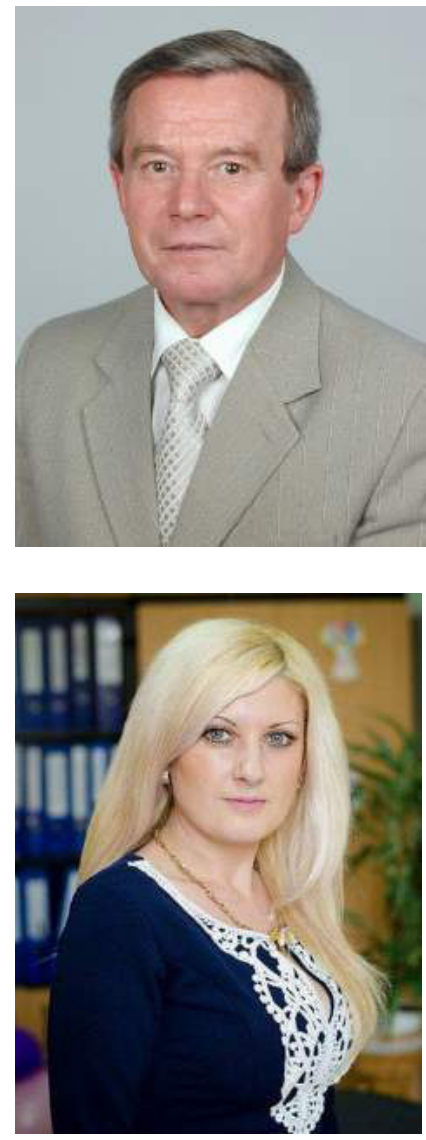

\section{Іван Руснак,}

доктор педагогічних наук, професор, завідувач кафедри іноземних мов, Хмельницька гуманітарно-педагогічна академія (м. Хмельницький, Україна)

\section{Ivan Rusnak,}

Doctor of Pedagogical Sciences, Professor, Head of the Department of Foreign Languages, Khmelnytsky Humanitarian and Pedagogic Academy (Khmelnytsky, Ukraine) ivan_rusnak49@ukr.net

\author{
Наталія Ситник, \\ кандидат педагогічних наук, асистент \\ кафедри педагогіки та методики початкової освіти, \\ Чернівецький національний університет \\ імені Юрія Федьковича \\ (м. Чернівці, Україна) \\ Natalia Sitnik, \\ PhD in Education, teaching assistant. Department of \\ Pedagogy and Methodology of Primary Education \\ Yurii Fedkovych Chernivtsi National University \\ (Chernivtsi, Ukraine) \\ nataliiasytnyk82@gmail.com
}

УДК 37.014.005.412(477/71 ) «19/20»(09)(043.3)

\title{
СПІВПРАЦЯ УНІВЕРСИТЕТІВ УКРАЇНИ ТА КАНАДИ ЯК ЧИННИК РОЗВИТКУ ВІТЧИЗНЯНОї ВИЩОЇ ОСВІТИ
}

Анотація. У статті розкривається еволюція українсько-канадських зв'язків у галузі вищої освіти. Акцентується увага на ролі наукових й освітніх відносин між університетами України та Канади в розбудові вітчизняної системи вищої освіти як складової світового освітнього простору. Аналізуються напрями, форми і види співпраці між університетами Канади і України впродовж другої половини XX - початку XXI ст. Обґрунтовується позитивний вплив співробітництва Канади та України на підвищення кваліфікації педагогічних кадрів незалежної Української держави та підготовку науково-педагогічних працівників для вітчизняної системи вищої освіти.

Ключові слова: українсько-канадські освітні зв'язки, вітчизняна вища освіта, університети України, університети Канади, фрорми міжуніверситетської співпраці в галузі освіти та науки.

\section{COOPERATION OF UKRAINIAN AND CANADIAN UNIVERSITIES AS A FACTOR OF DOMESTIC HIGHER EDUCATION DEVELOPMENT}

Abstract. The article reveals the evolution of Ukrainian-Canadian ties in the field of higher education. Attention is drawn to the role of scientific and educational relationship between Ukrainian and Canadian Universities in the development of domestic higher education system as a part of international educational space. Directions, forms and types of cooperation between Ukrainian and Canadian Universities during the second part of XX - the beginning of XXI century are analyzed. The positive impact of Canadian cooperation on advanced training of pedagogical staff in independent Ukrainian State and scientific-pedagogical staff training for domestic system of higher education has been substantiated.

Keywords: Ukrainian-Canadian educational ties, domestic higher education, Ukrainian Universities, Canadian Universities, types of cooperation between Universities in the field of education and science. 


\section{ВСТУП}

Постановка проблеми. В умовах швидкозмінного сьогодення, динаміку розвитку якого визначають глобалізаційні процеси планетарного масштабу, майбутнє людської цивілізації у значній мірі залежить від взаєморозуміння між різними народами світу, співпраці провідних і менш розвинутих держав у вирішенні питань політичного, соціальноекономічного, екологічного, культурного, наукового та освітнього характеру, об'єднання зусиль у збереженні життя на Землі і самої планети. Розвиток сучасних суспільних реалій спонукає вчених і педагогів до спільного пошуку ефективних засобів вирішення проблем як локального, так і глобального значення, від яких залежить прогрес усього людства.

Успішність інтеграції системи вищої освіти України у європейський і світовий освітній простір також узалежнена від наявності ефективного співробітництва як на міжнародному, так і на міжвузівському рівні. 3 проголошенням незалежності нашої держави діяльність органів управління освітою, а також окремих вищих навчальних закладів та наукових установ у цій сфері значно активізувалася і з кожним роком цілком закономірно набуває прискорення. Проте аналіз наявної практики міжнародної співпраці, яка загалом позитивно впливає на ефективність і якість діяльності вітчизняних закладів вищої освіти, ще не набула системного характеру і не привернула належної уваги дослідників як в Україні, так і за її межами, хоча потреба в них, безперечно, є.

\section{МЕТА І ЗАВДАННЯ ДОСЛІДЖЕННЯ.}

Мета дослідження полягає в аналізі становлення і розвитку наукових та освітніх зв'язків між університетами України та Канади і визначенні їх ролі в розбудові вітчизняної вищої освіти.

Завдання дослідження.

1. Виокремити передумови становлення і розвитку українсько-канадських зв'язків у галузі вищої освіти.

2. Проаналізувати напрями, зміст, шляхи і форми співробітництва університетів України та Канади в другій половині XX - на початку XIX ст.

3. Визначити роль українсько-канадської співпраці у реформуванні системи вищої освіти в Україні, збагаченні її прогресивними зарубіжними педагогічними здобутками.

МЕТОДИ ДОсЛІДЖЕННЯ: для досягнення мети і виконання поставлених завдань використано такі методи наукового пошуку: історико-генетичний аналіз - для виявлення передумов зародження й розвитку українськоканадського співробітництва в соері університетської освіти; історико-ретроспективний аналіз матеріалів періодичних видань, документації громадських організацій та державних органів, наукової літератури - для визначення напрямів, змісту, шляхів і форм співробітництва університетів України та Канади і його ролі в збагаченні освітньої системи України зарубіжним педагогічним досвідом.

\section{РЕЗУЛЬТАТИ ДОСЛІДЖЕННЯ}

Розвиток українсько-канадських зв'язків у галузі культури в другій половині XX ст. зумовив встановлення освітніх зв'язків між Україною та провінцією Саскачеван. Вважаємо цей факт не випадковим. Адже іммігранти з українських земель ще наприкінці XIX ст. були одними з перших поселенців у її преріях і перетворили дикі степи в родючі землі. Тут вони розбудовували свою «малу Україну», творили матеріальні і духовні цінності, які допомагали їм зберігати свою етнокультурну самість і водночас збагачували самобутню канадську етнічну мозаїку. У цій провінції сформувалася й успішно діяла потужна система українських культурно-просвітницьких установ та рідномовного шкільництва, що стали основними чинниками фрормування української спільноти як етносоціокультурного френомена в поліетнічному середовищі Канади й забезпечують її життєдіяльність у державі поселення / нароження уже впродовж другого століття.

Прагнучи забезпечити майбутність української громади в Канаді, Саскачеванський університет першим у цій країні в 1944 р. ввів офріційне навчання української мови як неакредитованого курсу. Успішно діяло тут Саскачеванське товариство вчителів української мови [3, с. 30-34]. Українці також працювали на різних посадах у місцевому міністерстві освіти та в університеті. Вважаємо, що якраз ці чинники найбільшою мірою сприяли тому, що в 1977 р. Саскачеванський університет став першим північноамериканським університетом, який підписав угоду про співпрацю з університетом в Радянській Україні, а саме з Чернівецьким державним університетом.

Співпраця двох вищих навчальних закладів, незважаючи на ідеологічне протистояння суспільних систем УРСР й Канади, розвивалася досить швидко. Вже наступного літа м. Чернівці відвідала група деканів - Мак Келум, Нільсон і Черрі, яка, відповідно, мала на меті вияснити можливості взаємодії в галузі вищої освіти, а також у сфері природничих та гуманітарних наук. У вересні того ж 1978 р. Канаду вперше з офріційним візитом відвідала делегація Чернівецького університету на чолі з ректором К. Червінським. До неї входили декан історичного факультету Ю. Макар і старший викладач кафедри англійської мови Р. Турчин. Цей візит завершив перший етап співпраці взаємне ознайомлення з навчальним процесом і постановкою та можливостями обміну в науково-дослідній галузі.

Відповідно до угоди, перша група канадських студентів прибула до Чернівців улітку 1978 р. Очолила її тодішній керівник кафедри української мови Саскачеванського університету доктор Р. Франко. На восьмитижневу програму прибуло п'ять студентів. Вони вивчали українську мову, літературу, слухали лекції з історії та культури України. Однак тут виникли і певні проблеми. Слід зазначити, що українська сторона при складанні навчальних програм для канадських студентів не врахувала їхнього рівня володіння українською мовою. Організатори навчання вважали, що оскільки вони українського походження, то само собою повинні знати рідну мову. Канадські студенти загалом українською мовою володіли, але не настільки, щоб зрозуміти ті «високі мовні матерії», які розглядалися 
на заняттях цих перших, що далі стали традиційними, мовно-культурних курсів. Тож довелося програму перебудовувати вже в процесі їх роботи. Проте цей візит канадських студентів в Україну закінчився успішно.

Упродовж наступних кількох років із саскачеванськими студентами приїздив професор відділу загального мовознавства Торонтського університету Е. Бурштинський - високоерудована, віддана науці й навчанню молоді людина, котра зробила помітний вклад у розвиток співпраці двох університетів. До речі, професор Е. Бурштинський уможливив співпрацю на особистій основі науковцям Чернівецького і Торонтського університетів, допоміг науковою літературою та навчальними посібниками чернівецьким ученим і педагогам.

Однак, як слушно зазначає відомий діаспорознавець Ю. Макар, на перешкоді повноцінному обмінові між обома університетами у ті, тепер уже досить віддалені, роки стала тодішня загальнодержавна політика СРСР, яка декларувала бажання до міжнародної співпраці, а насправді не допускала (там, де могла) виїзду радянської, особливо студентської, молоді за кордон, щоб та «не заражалася нездоровим духом», або, крий Боже, «заразившись», не пробувала там залишитися. Як наслідок, протягом 1977-1979 рр. м. Чернівці відвідало 9 канадських студентів та 8 викладачів, два з них із студентами, а інші у складі офіційних делегацій. Проте з Чернівецького університету до Саскатуну поїхало за той же час лише 8 викладачів, з них троє входили до складу вищезгаданої офріційної делегації. Щоправда, на жаль, лише для співпраці загалом. Бо ті, хто відвідав Канаду, вже тоді змогли зібрати цікавий матеріал для своїх наукових досліджень і для вдосконалення навчального процесу в Чернівецькому державному університеті. Канадській стороні важко було зрозуміти, чому українська не виконує умов договору і не відправляє своїх студентів до Саскачеванського університету, адже обмін студентами мав бути стрижнем співпраці [6, с. 14].

Необхідно зазначити, що відрядити чернівецьких студентів до Саскачеванського університету вдалося лише наприкінці 80-х рp. XX ст., тобто під час горбачовської перебудови, а точніше, тільки напередодні розпаду Радянського Союзу. Першу таку делегацію очолював співавтор цієї статті - тоді доцент кафедри української літератури. 3 того часу і дотепер студенти Чернівецького університету постійно перебувають у своїх канадських партнерів, здебільшого на семестровому навчанні, групами по три особи. Найактивнішу участь у цій фрормі співпраці беруть студенти факультету іноземних мов, історичного, економічного та юридичного фракультетів. Вони набувають у Канаді не лише знання англійської чи французької мов. Туди вони тепер їдуть, володіючи ними на достатньому рівні, щоб могти засвоювати знання та набиратися досвіду в обраній ними фаховій галузі економіка, історія, міжнародні відносини, політологія, право, інноваційні технології навчання іноземних мов.

Потік канадських студентів у зворотному напрямі останніми роками дещо звузився. До Чернівецького національного університету імені Юрія Федьковича приїздять в основному на короткотривалі програми студенти-економісти на чолі з Б. Кіщуком [6, с. 14].

У процесі розвитку співпраці обох університетів угоди спочатку поновлювалися через кожні п'ять років, а починаючи з 1987 р., вони укладаються на десять років, але конкретизуються робочими програмами на кожних два-три роки.

Найбільш плідними виявилися наукові взаємини Чернівецького та Саскачеванського університетів. Вони розвивалися шляхом обміну інформацією, архівними і друкованими матеріалами, обміну науковцями в різних ділянках знань, проведення спільних наукових конференцій, видання за їх наслідками матеріалів та написання дисертацій.

Ще однією формою наукової співпраці між обома університетами є спільне проведення конференцій або запрошення на наукові форуми колег з університету-побратима. Першим таким форумом стала Всесоюзна етнографічна конференція, проведена в м. Чернівцях у 1984 р. спільно з Інститутом етнографії АН СРСР. У ії рамках уперше працювала українсько-канадська секція, на якій змістовні доповіді зробили Ю. Фотій і Л. Беррон із Саскачеванського університету, останній про канадських індіанців. 3 Торонтського університету доповідав Е. Бурштинський, а з Едмонтонського - Р. Білаш. Учасники конференції під час виїзду в гірські райони Чернівецької області ознайомилися з діяльністю освітніх та культурно-просвітницьких закладів на території Буковинських Карпат, провели польові дослідження. У жовтні наступного року в Саскатуні відбулася конференція «Українці в Канаді : погляд з обох боків океану». Чернівецький університет мав бути представлений п'ятьма науковцями. Проте з «ініціативи» Міністерства вищої і середньої спеціальної освіти СРСР на конференцію поїхали тільки двоє - доценти Ю. Макар та Л. Михайлина [9].

Важливим результатом активної співпраці двох університетів стало відкриття в травні 2005 р. в Чернівецькому національному університеті імені Юрія Федьковича Центру канадських студій імені Рамона Гнатишина. Його метою є забезпечення наукової бази для вивчення Канади як відкритого, плюралістичного і демократичного державного устрою та суспільства.

Для налагодження навчальної і наукової роботи при Центрі організовано Канадську бібліотеку, яка створює книжковий фонд наукової та дидактичної літератури, наочних посібників, відеоматеріалів. На даний час бібліотека нараховує понад дві тисячі примірників. Поповнення бібліотечного фонду здійснюється за допомогою Саскачеванського університету, громадських організацій, зокрема Фундації Гнатишина, приватних осіб українського походження з Канади, а також за сприяння Посольства Канади в Україні.

Окремою сферою діяльності Центру є навчальна робота. Оскільки Чернівецький університет став одним із провідних в Україні центрів канадознавства, відповідно навчальна робота зосереджується на викладанні наступних спеціалізованих курсів: «Канадська федерація: історія і сучасність», «Сучасна зовнішня політика Канади», «Адміністративно-територіальний устрій Канади», «Соціально-політична інтеграція українців у 
поліетнічне середовище Канади», «Українська імміграція до Канади: історія і сьогодення», «Українсько-канадські міжлюдські та міждержавні стосунки».

Відповідно до мети діяльності Центр канадських студій імені Рамона Гнатишина займається такими проектами: розширення стосунків із канадськими державними та регіональними установами; обмін науковцями та студентами з канадськими вищими навчальними закладами; дослідження в галузі канадських студій; поповнення фондів та вдосконалення діяльності бібліотеки Центру, включаючи on-line ресурси; збагачення профресійного досвіду студентів [7].

У лютому 2010 р. Центр організував першу в Україні конференцію, присвячену канадським студіям. Серед її учасників були канадознавці з Нідерландів, Ірландії, Польщі, Німеччини, Канади [2]. Значна частина виступів була присвячена порівняльному аналізу, взаєминам між Канадою й Україною та суто канадським темам, а в понад третині доповідей ішлося про різні аспекти українського життя в Канаді.

Співробітництво Чернівецького і Саскачеванського університетів, зокрема в ділянках історії, літератури, педагогіки, суттєво спричинилося до пожвавлення зацікавленості канадською проблематикою в університетських і науково-дослідних колективах усієї України. Чернівецький університет заслужено здобув визнання наукової громадськості України як один із провідних центрів канадознавства, а Саскачеванський університет єдиний на всю Північну Америку має таку тривалу співпрацю з українським університетом.

Співпраця двох університетів підсилювала академічні, культурні та мовні зв'язки і взагалі підвищувала в українській громаді Канади рівень зацікавленості Україною. Офіційне побратимство міста Саскатун із містом Чернівці представляє ще один із результатів цієї співпраці. Ініціатором налаштування освітніх зв'язків 3 Міністерством освіти України згодом стали й інші провінційні міністерства освіти Канади. Завдяки цьому в 1990 р. у відповідь на запрошення Міністерства народної освіти України представники міністерств освіти провінцій Саскачеван і Манітоба відвідали українські школи, вищі навчальні заклади для кращого ознайомлення з системою освіти нашої держави. Того ж самого року в ході візиту до Саскачевану посадових осіб міністерства освіти України було підписано спільну угоду про співпрацю в галузі освіти між міністерствами освіти України і Саскачевану, що стала такою першою угодою між провінційним міністерством освіти та Міністерством народної освіти України. Вона передбачала співпрацю з широкого кола питань, обмін делегаціями учнів, учителів, співробітництво між школами, педагогічними інститутами, органами управління освітою, а також обмін та спільну підготовку і видання шкільних програм, підручників, іншої навчальної літератури.

Уже з перших років реалізації угоди стало очевидним, що обидві системи освіти $є$ відмінними, різноманітними. Тому логічним першим кроком для налагодження співпраці між освітянами обох країн стало взаємне ознайомлення із цими відмінностями, а також пошук спільного в даній сфері.

У результаті цих зусиль 11-23 липня 1994 р. було проведено українсько-канадську педагогічну конференцію в містах Одесі, Херсоні і Миколаєві, яка за своєю метою і тематикою була подібною до попередньої конференції 1991 р. Одночасно в м. Одесі працювало п'ять авторських курсів підвищення кваліфікації вчителів, викладачами яких були канадські професори, працівники міністерства освіти та шкільних рад провінції Саскачеван. Вони розглядали теми адміністрування освітою, психології навчання та методів викладання англійської, фрранцузької й української мов.

Протягом двох тижнів педагоги й науковці з Канади ділилися своїм досвідом із шістьма групами учителів України. Навчання відбувалося від понеділка до п'ятниці по п'ять годин щоденно. Ю. Жеребецький зустрічався з учителями, які вчать українську мову в російськомовних школах східних областей України. В. Курилів спілкувалася з учителями історії. М. Вербови-Онух та Г. Дитиняк обмінювалися досвідом з учителями початкових класів (одна - з методики навчання мови, а друга - 3 навчання суспільних наук). О. Винницька працювала 3 учителями англійської мови. А. Мельник ділилася досвідом роботи з адміністраторами шкіл [1].

Під час курсів основними формами роботи були дискусії в групах та робота над груповими й індивідуальними проектами. Основна мета курсів полягала в тому, щоб якнайбільше ознайомити українських педагогів із західною методикою викладання окремихпредметів, а також сформувати в учителів та адміністраторів уміння критично аналізувати самих себе та у співпраці з колегами доходити до розв'язання спільних проблем. Водночас кожен із викладачів старався підкреслити, що вихователь, учитель мусить активно спостерігати за дітьми та учнями, пристосовуючи свої знання до їхніх потреб і зацікавлень, а в ролі адміністраторів - спостерігати за учителями і пристосовуватися до їхніх запитів та інтересів. Безперечно, велика частина такого навчання проводилася з використанням особистого досвіду та власного прикладу, коли педагоги з Канади змушені були змінювати свої плани, зустрівшись із реаліями щоденного життя в Україні, та пристосовуватися до потреб конкретних учителів - слухачів курсів.

Викладачі педагогічного факультету Саскачеванського університету, які брали участь у цих конференціях, зацікавилися освітніми справами в Україні і звернулися до провінційного міністерства освіти з проханням допомогти їм налагодити офіційні зв'язки з вищими навчальними закладами України, які проводять підготовку вчителів. У 1995 р. Міністерство освіти Саскачевану організувало візит трьох канадських професорів до Дрогобицького педагогічного університету, Прикарпатського університету та Одеського педагогічного університету, з якими педагогічний факультет підписав угоди про співробітництво в галузі освіти. Того ж року Саскачеванський університет запросив представників цих навчальних закладів на п'ятитижневу так звану програму орієнтації щодо канадської системи освіти. Міністерство освіти Саскачевану допомогло вченим 3 України виконати цю програму, в результаті чого зацікавлені сторони розробили конкретні пропозиції щодо 
спільних проектів у галузі управління освітою, підготовки вчителів та психології навчання. У наступному році три професори педагогічного фракультету Саскачеванського університету відвідали Одеський та Прикарпатський університети і в кожному з них провели 10-денні курси з управління освітою. Згодом представники цих українських навчальних закладів відвідали Саскачеванський університет, де виконали шеститижневу післядипломну програму «Управління освітою» і «Психологія навчання» [1, с. 21-26].

У 1995 р. Міністерство освіти Саскачевану та педагогічний фракультет Саскачеванського університету спільно із Прикарпатським університетом влаштували для канадських студентів 8-тижневу практику в середніх загальноосвітніх школах Івано-Франківської області [4, с. 7-20].

Результатом розвитку українсько-канадських зв'язків у галузі освіти стало створення в Національному університеті «Острозька академія» (НаУОА) в січні 2002 р. Інституту досліджень української діаспори [5]. Його метою $є$ вивчення життя, діяльності, творчого й наукового доробку українців, які проживають поза межами України, а також розширення й поглиблення наукових та культурних зв'язків із українською діаспорою.

До основних напрямів діяльності інституту належать: опрацювання науковихпроблем, пов'язаних із вивченням різних аспектів життя української діаспори, публікація наукових збірників, монографічних та довідникових видань; розробка навчальних програм і університетських лекційних курсів, пов'язаних із різними аспектами життя та діяльності діаспори; опрацювання навчальних посібників для середньої та вищої школи; організація наукових конференцій і семінарів з проблем дослідження української діаспори; сприяння у запрошенні вчених з діаспори для викладання в Національному університеті «Острозька академія»; співпраця з українськими науковими установами та університетами у вивченні проблем, пов'язаних із життям та діяльністю закордонного українства; формування наукової бібліотеки й архіву.

Міжнародне співробітництво з канадськими партнерами в галузі вищої освіти активно розвиває Національний університет «Києво-Могилянська академія» (НаУКМА), яка відновила свою діяльність у 1991 р. майже одночасно з проголошенням незалежності України. Завдяки наполегливій праці викладачів і студентів академія успішно розвивається і знов підтвердила свій статус провідного осередку української духовності та науки. Великий внесок у розбудову академії зробили українці діаспори. За їх кошти обладнано багато сучасних аудиторій, а бібліотечні фронди поповнились зібраннями книг благодійників. Про це всім нагадують вивішені біля аудиторій пам'ятні таблички [8].

Важливим напрямом міжнародного співробітництва $є$ співпраця НаУКМА з Канадським інститутом українських студій Альбертського університету. Укладена угода включає наукову співпрацю у дослідженні історії, культури та української літератури XVI - XX ст., зокрема вивчення і видання стародруків та рукописних текстів полемічних, дидактичноморалістичних і гомілетичних творів XVI - XVIII ст.; дослідження окремих літературних та історико-соціальних аспектів сучасної України; проведення семінарів і обміни студентами, аспірантами та докторантами для короткочасних навчальних і дослідницьких відряджень; обміни книгами, журналами та іншою літературою й інфрормацією.

Розширенню українсько-канадських освітніх зв'язків сприяє співпраця НаУКМА з Університетом Західного Онтаріо (Канада). Представники цього канадського університету (віце-президент з досліджень та міжнародних відносин Т. Хьюїт, виконуючий обов'язки декана факультету соціальних наук Дж. Макмалін, декан фракультету інформації і медіастудій Т. Кармайкл та професор історичних і політичних наук М. Дичок) під час перебування в Україні зустрічалися з президентом НаУКМА С. Квітом та іншими представниками адміністрації університету, обговорювали питання розширення зв'язків між різними фракультетами і відділами шляхом обміну викладачами та студентами, науково-дослідної співпраці і співробітництва на рівні управління університетами, спільного контролю, що, ймовірно, призведе до отримання подвійного диплома випускниками академії.

НаУКМА ініціював заснування міждисциплінарної програми з канадських студій, яка має великий потенціал для розвитку і фрінансується урядом Канади.

\section{ВИСНОВКИ ТА ПЕРСПЕКТИВИ ПОДАЛЬШИХ ДОСЛІДЖЕНЬ}

Основними напрямами співробітництва університетів України та Канади в другій половині XX - на початку XIX ст. визначено:

- обмін досвідом з питань реалізації освітньої політики та впровадження сучасних технологій організації навчального процесу;

- обмін студентами, аспірантами, викладачами й науковцями;

- створення умов для вивчення офріційних / державної мов країн-партнерів на території кожної із них, включаючи обмін фахівцями, які спеціалізуються в галузі лінгводидактики і мовознавства;

- обмін досвідом у сфері педагогіки, підготовка спільних видань наукової, навчально-методичної літератури та навчальних посібників;

- сприяння проведенню конференцій, семінарів, симпозіумів та наукових досліджень на рівні вищих навчальних закладів і наукових установ тощо.

Отже, співробітництво між університетами України та університетами Канади в галузі освіти й науки, що зародилося у 70-х роках XX ст. і триває на сучасному етапі, не втратило своєї актуальності і становить важливу сторінку стосунків двох країн на шляху до збереження ідентичності українців за кордоном, оскільки саме освіта $€$ тим важливим чинником, який дає не лише знання рідної мови, а й забезпечує національно-патріотичне виховання наших співвітчизників в епоху процесів глобалізації та асиміляції й розбудови державності в Україні. 


\section{СПИСОК ВИКОРИСТАНИХ ДЖЕРЕЛ}

[1] Винницька О. Освіта в Україні і роля Діяспори. Відгукніться. 1994. Ч. 8. С. 21-26.

[2] Візит д-ра Романа Єренюка до Міжнародного інституту освіти, культури та зв'язків з діаспорою. URL: http://www.miok.lviv. ua/index.php.

[3] Жеребецький Ю. Освітні Контакти Міністерства Освіти Саскачевану й України.

Відгукніться. 1994. Ч. 8. С. 30-34.

[4] Жеребецький Ю. Освітні зв'язки з Україною. Діаспора як чинник утвердження держави Україна у міжнародній спільноті : । міжнар.наук.конф. (Львів, 8-10 берез. 2006 р.). Львів : Сполом, 2006. С.7-20.

[5] Інститут дослідження української діаспори. URL: http://www.oa.edu.ua/ua/institutes/diaspora.

[6] Макар Ю. Чернівецький і Саскачеванський університети : 25 років співпраці. Історико- політичні проблеми сучасного світу : зб. наук. статей. Чернівці : Рута, 2002. Т. 9. С. 11-19.

[7] Опис центру канадських студій ім. Р. Гнатишина, цілі та напрямки діяльності. URL: http://rhcsc.chnu.edu.ua/index. php?page=ua/4description_ua.

[8] Підписано угоду між КІУСом і Києво-Могилянською академією. URL: http://www.ualberta.ca/CIUS/ announce/media

[9] П'ятий всесвітній форум українців. URL: http://www.radiosvoboda.org/content/article/24302283.html.

\section{REFERENCES (TRANSLATED AND TRANSLITERATED)}

[1] Vynnycjka O. Osvita v Ukrajini i rolja Dijaspory (Education in Ukraine and the role of the Diaspora). Vidghuknitjsja. 1994. Ch. 8. S. 21-26. (in Ukrainian)

[2] Vizyt d-ra Romana Jerenjuka do Mizhnarodnogho instytutu osvity, kuljtury ta zv'jazkiv z diasporoju (Visit of Dr. Roman Yereniuk to the International Institute for Education, Culture and Relations with the Diaspora). URL: http://www.miok.Iviv.ua/index.php. (in Ukrainian)

[3] Zherebecjkyj Ju. Osvitni Kontakty Ministerstva Osvity Saskachevanu j Ukrajiny (Educational Contacts of the Ministry of Education of Saskatchewan and Ukraine). Vidghuknitjsja. 1994. Ch. 8. S. 30-34. (in Ukrainian)

[4] Zherebecjkyj Ju. Osvitni zv'jazky z Ukrajinoju (Educational ties with Ukraine). Diaspora jak chynnyk utverdzhennja derzhavy Ukrajina u mizhnarodnij spiljnoti : I mizhnar.nauk.konf. (Ljviv, 8-10 berez. 2006 r.). Ljviv : Spolom, 2006. S.7-20. (in Ukrainian)

[5] Instytut doslidzhennja ukrajinsjkoji diaspory (Institute for the Study of Ukrainian Diaspora). URL: http://www.oa.edu.ua/ua/ institutes/diaspora. (in Ukrainian)

[6] Makar Ju. Chernivecjkyj i Saskachevansjkyj universytety : 25 rokiv spivpraci.Istoryko- politychni problemy suchasnogho svitu (Chernivtsi and Saskatchewan Universities: 25 years of cooperation. Historical and political problems of the modern world): $\mathrm{zb}$. nauk. statej. Chernivci : Ruta, 2002. T. 9. S. 11-19. (in Ukrainian)

[7] Opys centru kanadsjkykh studij im. R. Ghnatyshyna, cili ta naprjamky dijaljnosti (Description of the Canadian Student Center R. Gnatyshyn, goals and directions of activity). URL: http://rhcsc.chnu.edu.ua/index.php?page=ua/4description_ua. (in Ukrainian)

[8] Pidpysano ughodu mizh KIUSom i Kyjevo-Moghyljansjkoju akademijeju (An agreement was signed between CIUS and the KyivMohyla Academy). URL: http://www.ualberta.ca/CIUS/ announce/media (in Ukrainian)

[9] P'jatyj vsesvitnij forum ukrajinciv (Fifth World Forum of Ukrainians). URL: http://www.radiosvoboda.org/content/article/24302283. html. (in Ukrainian) 